\title{
Funding the Australian Resources Investment Boom
}

\author{
Ivailo Arsov, Ben Shanahan and Thomas Williams*
}

Investment by the Australian resources sector has risen steadily since the early 2000 s to be at record levels. Most of the investment has been made by publicly listed companies, with contributions split evenly between Australian and foreign listed companies. The funding for this investment has overwhelmingly come from the profits generated by these companies. External funding sources, such as new debt and equity issuance, have played only a limited role.

\section{Introduction}

In the mid 2000s, the prices for commodities used in steel and energy production commenced a sharp and sustained increase driven by the rapid industrialisation and urbanisation of emerging economies, particularly China (Holloway, Roberts and Rush 2010). With global supply unable to match the unanticipated growth in demand, commodity prices reached very high levels. As a result, the value and profitability of Australia's resources exports rose substantially (Graph 1).

In response, resources producers increased their investment expenditure as they sought to boost output to satisfy the new sources of demand for their products and capitalise on their increased profitability. This has led to the largest resources investment boom in Australian history (Connolly and Orsmond 2011; Rayner and Bishop 2013). Investment spending in the Australian resources sector has risen from just under 2 per cent of GDP in 2002/03 to 7 per cent of GDP in 2011/12, thus driving a significant part of the economic growth over the past eight years. The Australian resources investment boom has been part of a broader global boom, as resources companies have sought to expand their production capacity.

* The authors are from Domestic Markets Department. They would like to thank Rachael McCririck for her contribution. They would also like to thank Lynda Turnbull and Nicole Berroya for their capable research assistance.

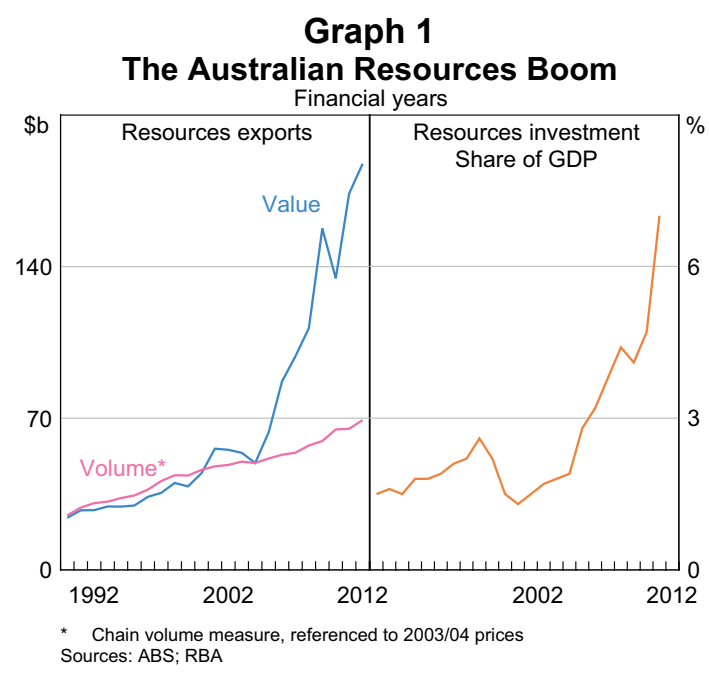

Given the importance of the resources boom for the Australian economy, it is worth understanding how the resources investment has been funded. This article examines the funding of the resources boom in Australia using a bottom-up approach that combines publicly available project-level data on resources sector investments with information from listed companies' financial statements. The analysis focuses on investment in new projects and expansion of existing projects. The next section examines the type of entities that have been behind the resources sector projects undertaken in Australia during the resources boom. Since most of these entities are publicly listed companies, knowing how these 
companies have funded themselves is equivalent to knowing how the resources investment boom has been funded. The subsequent section analyses how these publicly listed companies have funded their global physical investments since 2003. These findings are then combined to arrive at an overall understanding of how the Australian resources boom has been funded.

\section{The Australian Resources Investment Boom}

Between 2003 and 2012, investment in new projects and expansions of existing capacity in the resources sector is estimated to have totalled \$284 billion.' Detailed analysis of project-level data on the projects completed since 2003 or still underway at the end of 2012 suggests that Australian listed companies and other Australian-based entities have accounted for 54 per cent of this, with the balance coming from foreign entities (see Appendix A for details on the methodology used to construct these estimates). ${ }^{2}$ The overwhelming majority, over 90 per cent, of the investment has been by publicly listed companies, with private companies and government entities playing only a minor role (Graph 2).

Consistent with the global boom in demand for energy commodities and those used to produce steel, investment has been predominately in iron

1 This figure is based on the ABS measure of investment in buildings and structures in the resources sector for the financial years from 2004 to 2012 (ABS Cat No 5204.0) and estimates for the December half 2012 and the June half 2003 based on the quarterly ABS capital expenditure survey (ABS Cat No 5625.0). The buildings and structures component is used as it is the most comparable measure to the value of investment derived from the project-based estimates. The majority of spending on new resources projects should be reflected in their construction expenditure, which is captured in the ABS's measure of investment in buildings and structures. Relatively little of the spending on new projects is on machinery and equipment; most of what is reported in this category by the ABS is likely to be spending on the replacement of existing machines and equipment. Indeed, trends in the two categories since the start of the resources boom reflect this. Starting in 2003 from similar levels, the value of the annual investment in buildings and structures has increased nearly 14 times while the value of the annual investment in machinery and equipment has increased only $2 \frac{1}{2} 2$ times.

2 In this analysis, BHP Billiton and Rio Tinto, which have dual listings in Australia and the United Kingdom, are treated as Australian listed companies. A large share of the Australian listed resources sector is foreign owned and the impact of this is discussed later in this article.

\section{Graph 2}

Australian Resources Investment

Between 2003 and 2012

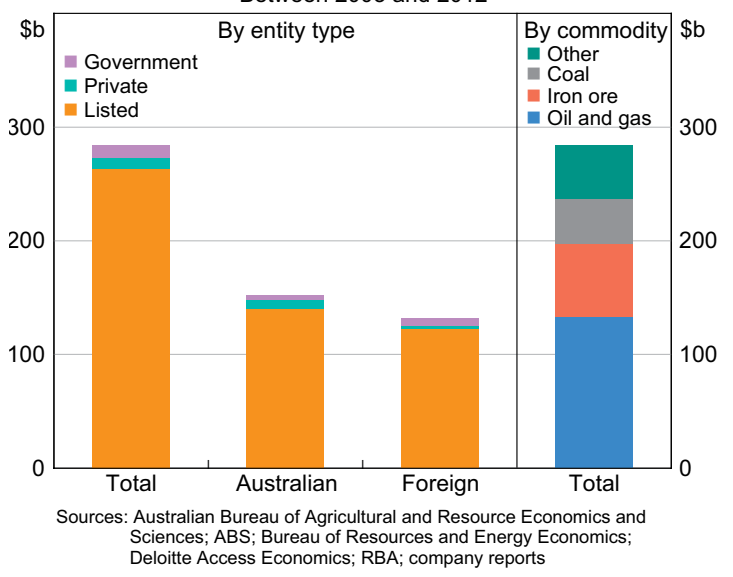

ore, coal, oil and gas, with these four commodities accounting for 84 per cent of the investment in physical infrastructure during the boom. ${ }^{3}$ The remaining 16 per cent of investment has been across a relatively broad group of commodities, consisting primarily of base metals (including aluminium, alumina and bauxite) and gold.

The financial statements of publicly listed resources companies provide information about how the majority of entities involved in the resources boom have funded themselves.

\section{Funding of Listed Resources Companies with Investments in Australia}

The companies analysed in this article include all listed Australian resources companies and the 37 foreign resources companies with the largest investments in Australian resources projects since 2003. ${ }^{4}$ The data for both the Australian and foreign companies include their operations in Australia and overseas. Financial statement data applicable to Australian operations only are not available because

3 Around 60 per cent of the investment in the oil and gas sector has been in major liquefied natural gas (LNG) projects that are currently under development

4 These 37 companies account for 95 per cent of the investment by foreign listed companies. 
companies report on a consolidated basis. The analysis combines financial statements data with the ownership data on Australian resources projects since 2003.

\section{Sources and uses of funds}

The Australian and foreign listed companies have funded themselves primarily with internal funds, while debt has also been used but to a lesser extent (Graph 3). ${ }^{5}$ Since the start of the resources boom, Australian companies have raised no equity in net terms, even though they raised substantial amounts of equity in 2009 in order to strengthen their balance sheets. Unlike earlier in the boom, the Australian companies have been returning greater amounts of capital to shareholders since 2011. The foreign companies have been consistently returning large amounts of capital to their shareholders, and, as a group, have not resorted to external equity funding at any time during the resources boom.

Funds raised by resources companies have typically been used to make new physical investments, with Australian and foreign companies using around

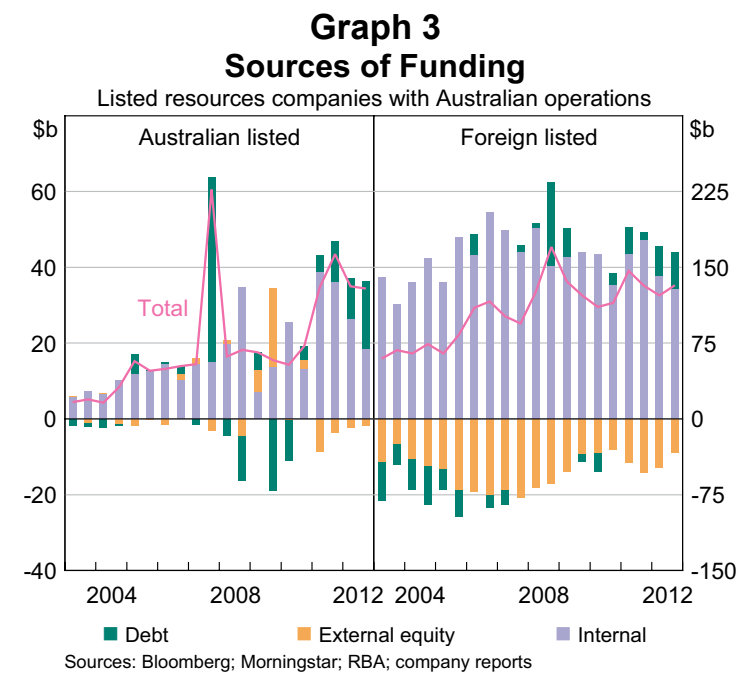

5 Since 2003, internal funding has accounted for 86 per cent and 150 per cent of total net funding flows for Australian and foreign listed resources companies, respectively. The share of internal funding is higher than in non-resources sectors. For example, other non-financial Australian listed companies have typically sourced 68 per cent of their net funding internally.
80 per cent of their funding for this type of spending (Graph 4). The rest of the funding has been used primarily to acquire existing assets from other companies, while funding for other investment purposes has been negligible. ${ }^{6}$

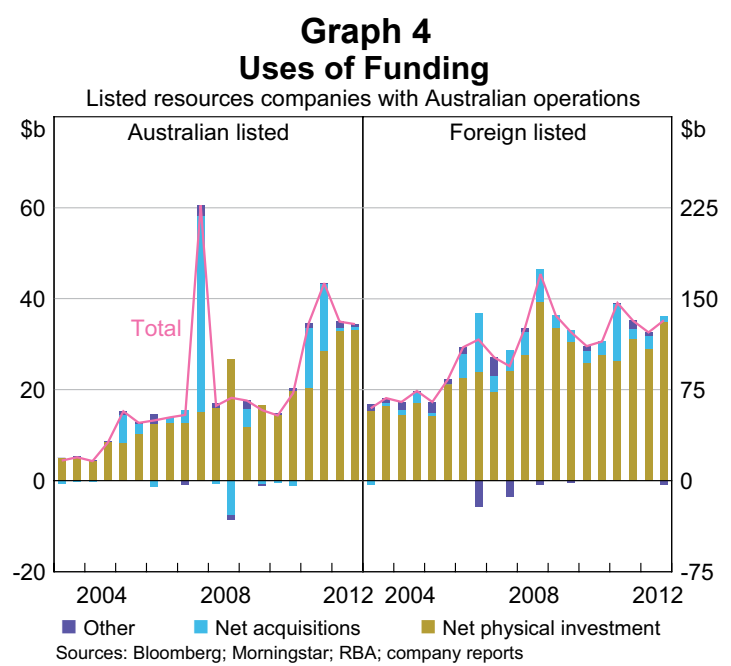

In general, companies' funding is fungible; however, certain types of funding are more suited to specific purposes. In particular, this is the case for acquisitions that are usually large relative to the acquirers' balance sheet, and require large one-off payments? Acquisitions are essentially transfers of assets within the sector and as such do not generate new physical investment or economic activity. These types of transactions are often funded with syndicated loans as other sources of funds may be insufficient or take too long to arrange. Given their distinct funding requirements, funding for acquisitions is excluded from the analysis in this article (see Appendix B for more details on the methodology). ${ }^{8}$

6 'Other investment' has accounted for just 3 per cent of total investment since 2003. It is comprised of a number of items that do not fall into the two main investment categories (acquisitions and physical investment) and it includes investments in financial assets.

7 For example, in the largest acquisition by an Australian listed resources company, Rio Tinto obtained around $\$ 40$ billion in syndicated loans to fund its purchase of Alcan in the second half of 2007. Rio subsequently undertook a $\$ 19$ billion equity capital raising in July 2009 as part of efforts to pay down this debt following the sharp fall in commodity prices at the end of 2008.

8 The analysis also abstracts from the 'other investments' category reported in companies' financial statements, although these investments tend to be small. 
Australian and foreign resources companies have funded the majority of their physical investment from internal sources, 80 per cent and 92 per cent, respectively (Graph 5). Australian companies have accessed external funding somewhat more, although this is still relatively small. This reflects their higher physical investment spending relative to their internal funds compared to foreign companies (discussed below).

\section{Graph 5}

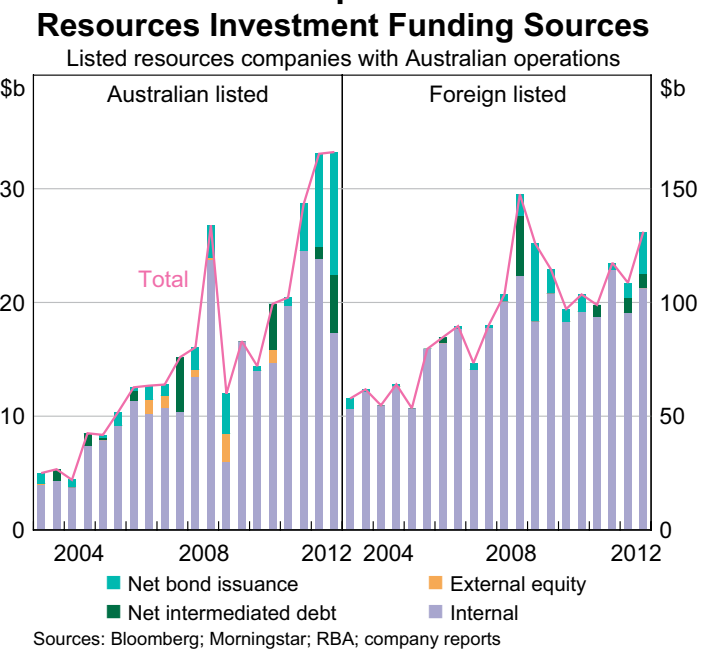

\section{Internal funding}

Most of the internal funding has come from resources companies' operating cash flows rather than from drawing down of accumulated cash balances, reflecting the large amounts of ongoing cash flows generated by resources companies. ${ }^{9}$ This reliance on internally sourced funds during the resources boom has been possible because of the large increase in commodity prices during the past decade, which has made resources companies very profitable. Australian and foreign resources companies have achieved an average annual return on assets (ROA) of 10 per cent and 7.2 per cent, respectively, since

9 Operating cash flows represent cash flowing into a firm's accounts during the reporting period, whereas net income is based on accrual accounting and is affected by a number of non-cash items (such as depreciation, increases in accounts receivable, etc). Cash flow measures are more relevant for funding.
2003, which has been significantly higher than the 4 to 5.5 per cent for other non-financial companies in Australia and overseas (Graph 6).

\section{Graph 6}

Return on Assets

Underlying profit divided by total assets

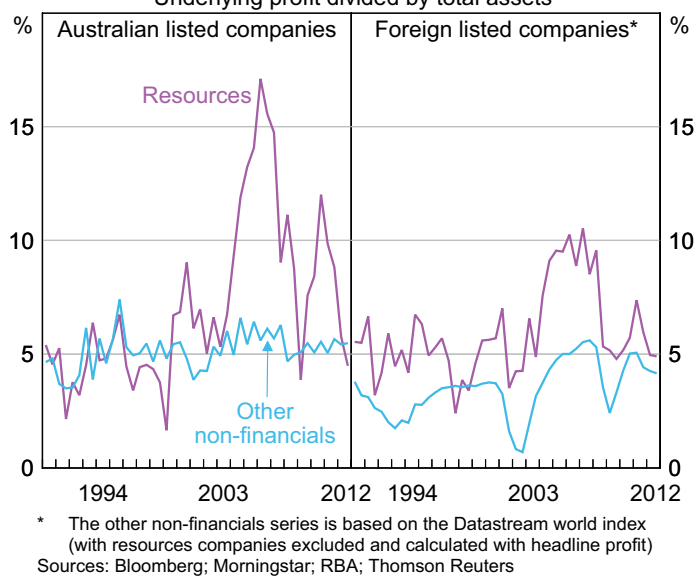

Resources companies' ROA was very high between 2004 and 2007, but has declined since; first with the downturns in commodity prices in late 2008 and early 2009 and then again since September 2011. Also, increasing operating costs appear to have contributed to the decline in resources companies' profitability.

Consistent with this, internal funding has declined since mid 2011, reflecting the sharp fall in the prices of a number of commodities over this period and the corresponding decline in profitability. However, physical investment has risen over this period because of the high level of already-committed projects. Companies have made more use of external sources to make up the shortfall.

\section{External funding}

Resources companies have used external funds to finance their physical investment during the boom to a much lesser extent than internal funds. Where they have accessed external funds, this has been mainly in the form of debt. Most of this debt funding has been raised in bond markets rather than from banks. This preference for bonds over intermediated debt to 
fund physical investment reflects the longer tenors available in bond markets, which more closely match resources companies' long investment horizons. The weighted average tenor of bond issuance by Australian and foreign resources companies has been around nine years since 2003. This is much longer than the typical tenor of syndicated loans extended to resources companies of four years. Another factor for the preference for bonds over bank loans is that some large resources companies have been able to borrow in bond markets more cheaply than banks. This is largely due to the global financial crisis, which caused investors to re-evaluate the risks associated with lending to banks and is evident in the pricing of credit default swaps (CDS); resources companies' CDS have generally traded at spreads lower than banks' CDS since late 2009 (Graph 7). ${ }^{10}$

The fact that resources investment has been such a significant contributor to economic growth in recent years, and that very little of this investment has been funded with bank debt, partly helps to explain why intermediated business lending in Australia has been lower in recent years than might be expected given the reasonable economic growth.

Resources companies' bond issuance has been conducted in a number of currencies, consistent with the diverse range of domiciles for the companies involved in the Australian resources boom. Nonetheless, nearly all issuance by the Australian resources companies, and around half of the issuance by the foreign companies, has been denominated in US dollars (Graph 8). This reflects the global nature of the products of these companies, which are usually priced in US dollars, and the depth of the US dollar bond market, which remains the largest and most liquid bond market globally. Around 20 per cent of issuance by foreign companies has been denominated in Japanese

10 This divergence in CDS premia has also been reflected in bond issuance spreads. For example, Rio Tinto (rated A-) issued a 5-year US\$1.25 billion bond in August 2012 at an equivalent spread of 197 basis points over Commonwealth Government securities (CGS). Australian banks, despite being more highly rated at AA-, were issuing at similar tenors around this time at spreads of 250 basis points over CGS.

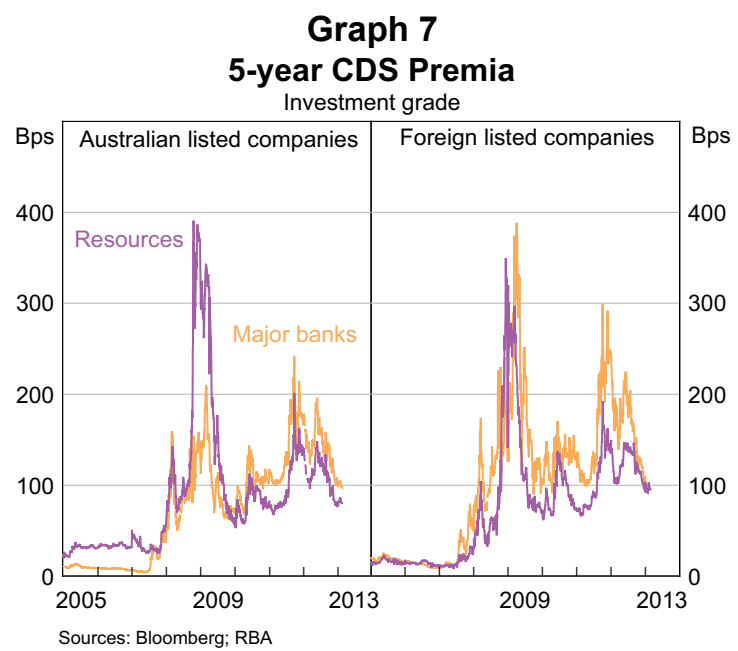

\section{Graph 8}

Resources Companies Bond Issuance

Listed resources companies with Australian operations

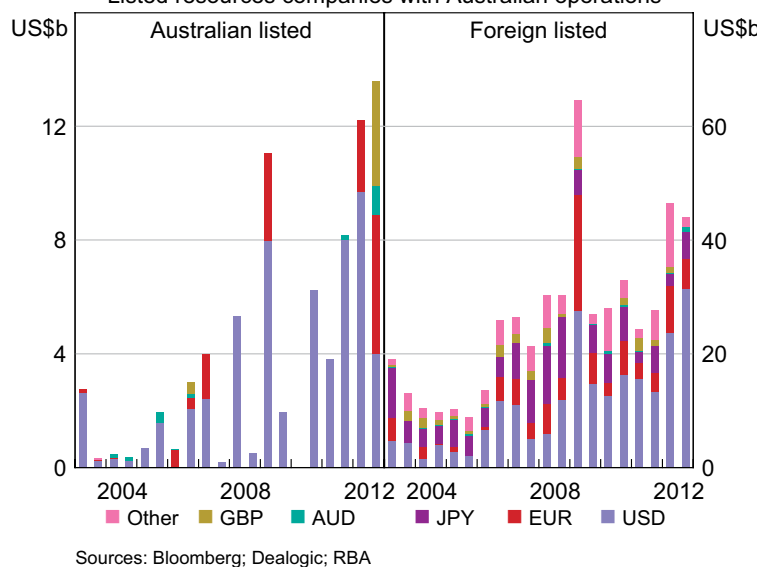

Sources: Bloomberg; Dealogic; RBA

yen, which is broadly consistent with the share of foreign companies investing in resources projects in Australia that are domiciled in Japan. There has also been significant euro-denominated bond issuance (around 15 to 20 per cent of the total) by both Australian and foreign companies, reflecting the size and significance of this funding market. Only around 3 per cent of issuance by Australian resources companies has been in Australian dollars, while foreign resources companies have issued less than 1 per cent of their bonds in Australian dollars. 
Very little physical investment has been funded with external equity. As noted above, in net terms Australian companies have raised no equity on average since 2003, while foreign companies have returned equity to their shareholders (Graph 9). Over this period, Australian resources companies have had a higher propensity to invest their operating cash flows in new physical investment than has been the case for non-resources companies. For Australian resources companies, the cash flow payout ratio - measured as dividends plus buybacks relative to cash flow from operations - has averaged 33 per cent since 2003, significantly lower than the 48 per cent payout ratio for other non-financial sectors. "While Australian resources companies issued equity in 2009 ( $\$ 25$ billion net), most of this was used to reduce debt levels, which had increased prior to the onset of the global financial crisis. The cash flow payout ratio of foreign resources companies has also been relatively low at 34 per cent, although in net terms they have been much more likely to return capital to their shareholders than Australian resources companies. This is because foreign resources companies have generated internal funding in excess of their physical investment and acquisition needs. The return of capital to shareholders by foreign companies has been driven primarily by a small number of large energy companies, with ExxonMobil, Chevron, Shell and BP returning a combined $\$ 600$ billion in capital to shareholders in the form of dividends and buybacks since 2003.

The low level of external equity funding, and indeed the return of capital to shareholders, reflects the fact that a high proportion of the industry is made up of large, well-established and highly profitable resources companies that have been generating profits in excess of their funding needs..$^{2}$ In contrast,

11 This measure is analogous to the more widely used dividend payout ratio - measured as dividends relative to net income - but is more consistent with the cash flow framework used throughout this article that is relevant to the analysis of funding.

12 This dominance of large companies may also explain the somewhat larger payouts to the shareholders of the foreign resources companies, because the foreign companies analysed include only the largest foreign companies with operations in Australia while all Australian listed resources companies are included.

\section{Graph 9 \\ Resources Companies Equity}

Cash Flows

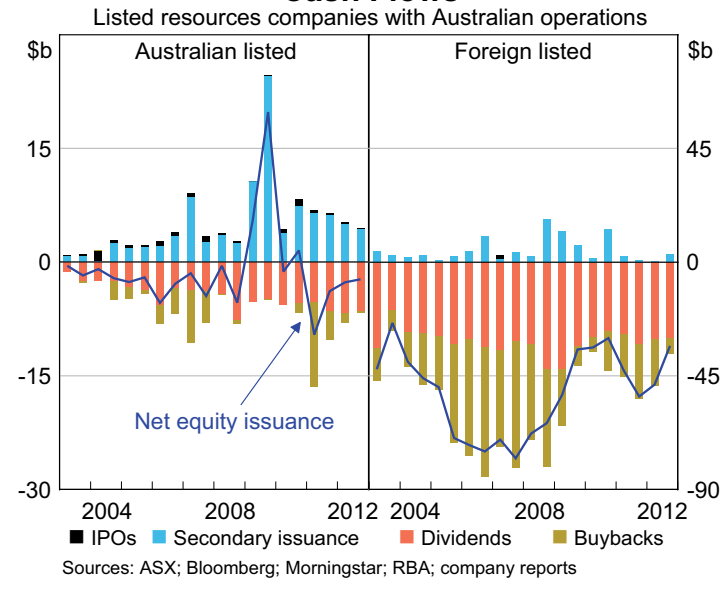

smaller resources companies are typically engaged in exploration activities and generally do not have established operations; therefore, these companies produce little or no internal funding (Williams 2012). Also, small companies, including the small resources companies generally, have limited access to debt financing, due to their inherent riskiness and their lack of cash flows to service debt. As a result, smaller resources companies have relied more heavily on external equity to fund their physical investment than have larger resources companies. The small resources companies have funded 73 per cent of their physical investment from external equity during the boom, which is significantly higher than the negligible funding from external equity of the larger companies (Graph 10).

Because Australian companies have funded most of their investment spending during the resources boom from internal sources, gearing in the sector has remained low. Book value gearing in the resources sector has averaged 41 per cent since 2003, much lower than the 62 per cent average for other non-financial corporations. Australian resources sector gearing reached a low of 24 per cent in 2010 but has risen since then as more of their physical investment has been funded with bond issuance. Despite the consistent return of capital to their shareholders, the book value gearing ratio of foreign 


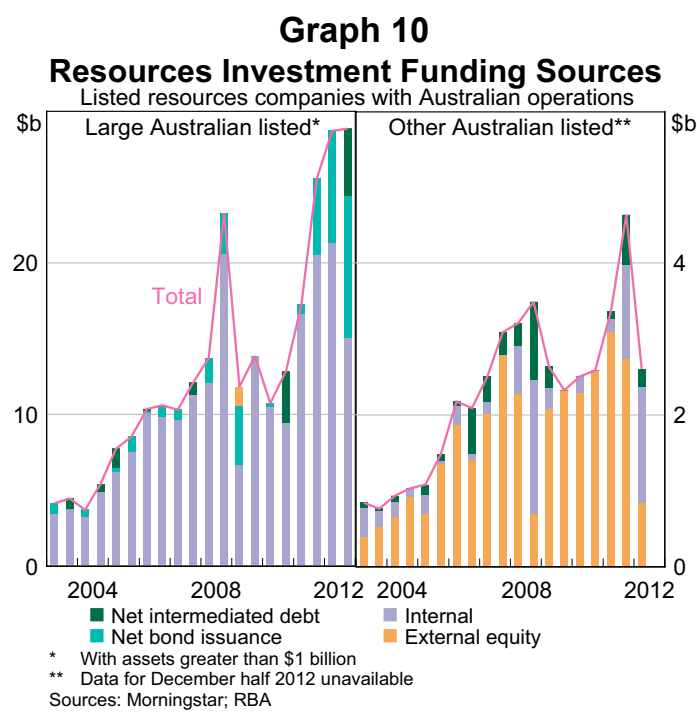

resources companies has remained low at 23 per cent on average since 2003. As discussed above, this is because these companies have generated internal funds well in excess of their physical investment requirements, so they have had little reason to raise debt.

\section{Funding the Australian Resources Investment Boom}

Combining the analysis from the two sections above provides insight into the funding of the Australian resources investment boom. Of the estimated \$284 billion spent since 2003 on investments in new projects and expansions of existing projects in the Australian resources sector, the vast majority - around 80 per cent - has been funded from the profits generated by listed companies (Table 1). Most of the total funding - around three-quarters - has been generated by 'current period' operating cash flows of listed companies, with drawdowns of existing cash stocks (cash accumulated from earlier periods) just 2 per cent of total funding.

External funding has financed only a small part of the Australian resources boom, with a little over 10 per cent funded with new debt and equity. Most of the external funding has come in the form of debt, with the majority raised in bond markets. Bank loans have played a very limited role in

Table 1: Funding of the Australian Resources Investment Boom ${ }^{(a)}$ Per cent of total

\begin{tabular}{lrrr}
\hline & Australian entities & Foreign entities & All entities \\
\hline Listed companies & 49 & 43 & 93 \\
\hline Of which: & & & \\
\hline Internal funding & 40 & 40 & 79 \\
\hline- Current operations & 38 & 39 & 2 \\
\hline - Existing cash & 1 & 1 & 12 \\
\hline Debt funding & 9 & 4 & 8 \\
\hline- Bonds & 6 & 3 & 4 \\
\hline- Loans & 3 & 1 & 1 \\
\hline Equity funding & 1 & 0 & 3 \\
\hline Private companies & 3 & 1 & 4 \\
\hline Government entities & 1 & 2 & $\mathbf{1 0 0}$ \\
\hline Total & $\mathbf{5 4}$ & $\mathbf{4 6}$ & \\
\hline
\end{tabular}

(a) Numbers may not add up exactly due to rounding

Sources: ABS; Australian Bureau of Agricultural and Resource Economics and Sciences; Bloomberg; Bureau of Resources and Energy Economics; Dealogic; Deloitte Access Economics; Morningstar; RBA; company reports 
funding resources investment..$^{13}$ Similarly, external equity has contributed only marginally to the funding of the resources boom, with the majority of equity raisings by the resources sector aimed at strengthening companies' balance sheets following large debt-funded acquisitions rather than funding new physical investments. Outside the listed sector, private companies and government entities have also played only a limited role in funding the resources boom, contributing around 7 per cent of the funding.

Funding of the Australian resources boom has been sourced extensively from overseas. The analysis here suggests that, at face value, around half of the physical investment during the boom has been funded from overseas (i.e. the share of the foreign-based entities). However, the actual use of foreign sources of funds is much higher than that. This is because Australian resources companies have raised the majority of their debt funding through bond issuance in foreign markets, particularly the United States. And, more importantly, where companies have partial foreign ownership, funding from internal sources is equivalent to partial funding from foreign sources. Consequently, since the Australian listed resources sector is around three-quarters foreign owned, the same large proportion of internal funding is attributable to foreign sources. ${ }^{14}$ Taking these factors into consideration suggests that around four-fifths of funding for physical investment has been sourced from offshore.

The inflow of foreign funding during the resources boom is reflected in the Australian balance of payments. Net foreign investment in the Australian resources sector has increased from around 0.5 per cent of GDP in 2007 to around 3 per cent of GDP

13 Although the share of funding from loans has increased recently as some of the large LNG projects under construction are being financed in part with syndicated loans.

14 This estimate is calculated by attributing 100 per cent foreign ownership to the foreign listings of shares in BHP and Rio Tinto and then applying the share of foreign ownership of Australian listed non-financial corporations, as measured by the ABS, to the remainder of Australian listed resources shares. in $2012 .^{15}$ The resources investment boom has contributed to the marked shift in the composition of capital inflows into the economy, with the increase in net capital inflows into the resources sector partially offsetting the decline in net capital inflows into the financial sector (Debelle 2010, 2011).

The balance of payments data also show that around three-quarters of all foreign investment in the resources sector has been in the form of foreign direct investment (FDI), which is broadly consistent with the findings from the analysis presented in this article (Graph 11). This has contributed to the increase in net FDI inflows into Australia over recent years. Since 2007, a large proportion of the FDI in the resources sector has been supplied through the reinvested earnings of the foreign owners of resources companies. In some cases, these capital flows are notional flows only as the funds have not left Australia, and are matched by notional income payments to foreign residents, which increases the net income deficit on the current account (RBA 2011).

Graph 11

\section{Resources Sector Capital Flows*}

Gross flows, share of GDP

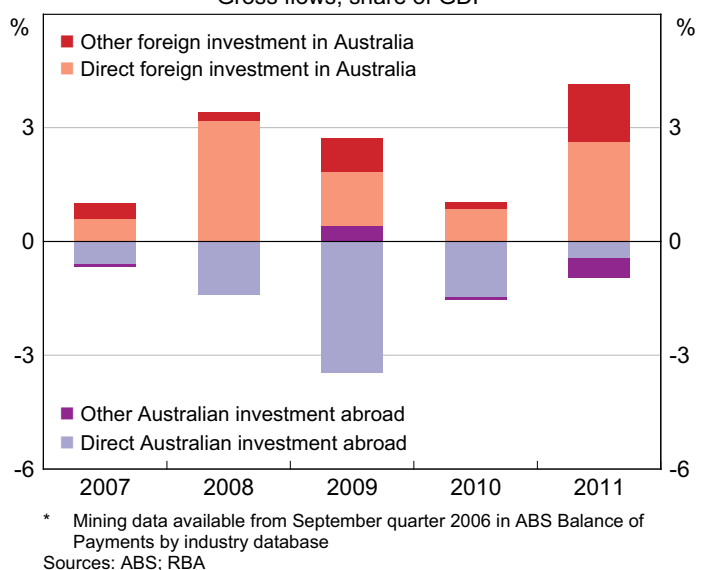

Sources: ABS; RBA

15 Sectoral balance of payments data is available only since September 2006 and does not cover the earlier part of the resources boom, which limits the time scope of this type of analysis. 


\section{Conclusion}

Investment in the Australian resources sector has risen over recent years to record levels. This investment has been funded predominantly from the profits generated by Australian and foreign listed resources companies with projects in Australia. This has come about because the high commodity prices received by resources producers have made them highly profitable. In contrast, the contribution to funding from external sources - debt and equity - has been small. The high share of funding of resources sector investment attributable to foreign residents has contributed to the marked shift in the composition of Australia's capital (financial) account over recent years. Net capital inflows into the resources sector have partially offset the decline in net capital inflows into the banking sector and have contributed to the increase in net FDI inflows into Australia. 4

\section{Appendix A}

A list of resources projects was compiled as an intermediate step to building a database of the entities involved in the resources boom. The list includes projects that have been completed, or commenced but not finished by end 2012, since the start of 2003. The list was sourced primarily from the 'Resources and Energy Major Projects' database compiled by the Bureau of Resources and Energy Economics (BREE) since October 2011, and earlier by the Australian Bureau of Agricultural and Resource Economics and Sciences (ABARES). Additional information was drawn from the Deloitte Access Economics Investment Monitor

For each project, data were compiled on the entity (or entities) involved, including its type (listed, private or government), its domicile, and its share of ownership in the case of joint venture projects. Ownership of each entity was attributed to its ultimate parent where possible.
Estimates for the investment expenditure already made on projects under construction but not yet completed were compiled from publicly available data, principally from listed companies' investor presentations and other reports. These estimates were added to the reported expenditure on completed projects to arrive at the physical investment during the resources boom so far (2003 to 2012), split by completion status, entity type and entity domicile (Graph A1).

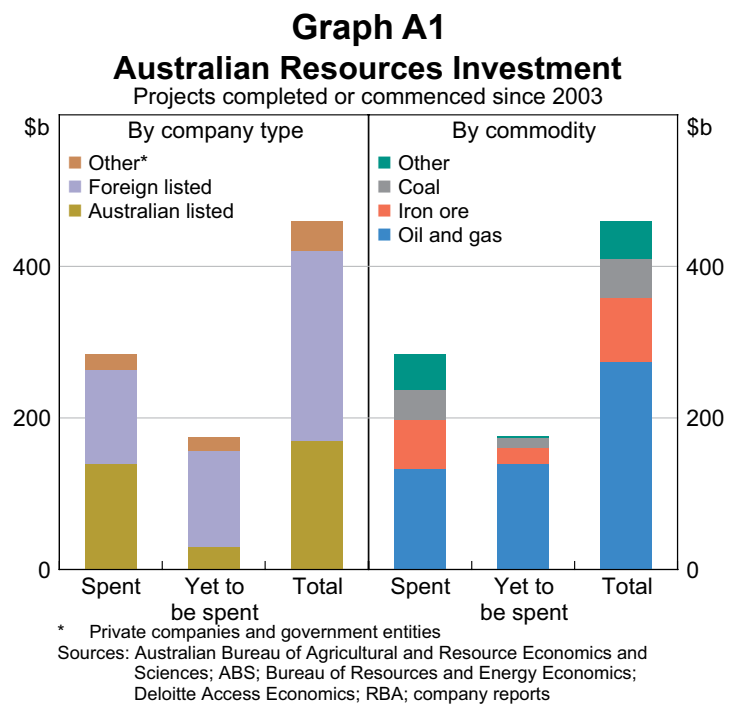

In total, the bottom-up analysis identified $\$ 266$ billion of project expenditure in the resources sector since 2003, which is around 95 per cent of the ABS's buildings and structures resources sector investment measure (the most comparable ABS measure). The discrepancy between the two is due to small projects not being captured in the bottom-up analysis and due to uncertainty over spending completed so far for projects underway. ${ }^{16}$ The bottom-up estimates have been scaled up proportionally so that the aggregate reconciles to the ABS measure.

\footnotetext{
16 The BREE (and earlier ABARES) project list only includes projects greater than $\$ 50$ million. Until October 2012, the BREE project list also included gold projects valued over $\$ 15$ million.
} 
The investment expenditure termed 'yet to be spent' on projects underway was derived as a residual between estimates of total project costs (as reported in the underlying databases) and estimates, from publicly available sources, of the spending that has been already made. It should not be interpreted as a forecast of future resources sector investment because it excludes projects that are under consideration for future development. There is a pipeline of such projects in the Australian resources sector and they are beyond the scope of this article.

\section{Appendix B}

This appendix sets out the use of company cash flow statements to calculate the funding of physical investment. ${ }^{17}$ The analysis is summarised in Table B1. It takes into account net interest and dividend payments (which are reported as uses of funds) in net debt and net external equity figures (which are reported as sources of funds). Net bank loans are calculated as the residual between the change in net debt, reported in the company's cash flow statement, and the company's net bond issuance.

As the analysis is concerned with the funding of net physical investment, adjustments are made to account for the funding of non-physical investment. This is achieved primarily by determining the internal, debt and external equity funding split of large mergers and acquisitions (M\&A) transactions, as these transactions tend to be funded very differently from other investments. These funding splits are determined from public disclosures by the relevant companies. The weighted average funding split for these large acquisitions is then applied to the remaining 'net acquisitions' data, resulting in an estimate of total M\&A funding. Finally, 'other investment' (which is generally small), is assumed to be funded in the same proportions as all non-M\&A investment. The end result is the funding profile of physical investment by listed companies involved in the Australian resources boom (Equation (1)).

$$
\text { Physical investment funding }_{j}=\text { Total funding }_{j}-{\text { Funding } M \& A_{j}-\text { Funding other investment }}_{j}
$$

where $j=$ internal funding, debt funding, or external equity funding

\section{Table B1: Sources and Uses of Funds}

\begin{tabular}{|c|c|c|}
\hline \multirow{3}{*}{ Sources of funds } & Internal & $=$ Operating cash flows + decrease in cash balances \\
\hline & Net debt & $\begin{aligned}= & \text { New bank borrowing }+ \text { new bond issuance }- \\
& \text { repayments of debt }- \text { net interest payments }\end{aligned}$ \\
\hline & Net external equity & $\begin{aligned}= & \text { New equity issuance }- \text { net dividend payments }- \\
& \text { buybacks }\end{aligned}$ \\
\hline \multirow{3}{*}{ Uses of funds } & $\begin{array}{l}\text { Net physical investment } \\
\text { (i.e. capex) }\end{array}$ & $\begin{aligned}= & \text { Purchases }- \text { proceeds from sales of property, plant } \\
& \text { and equipment (PPE) }\end{aligned}$ \\
\hline & Net acquisitions & $\begin{aligned}= & \text { Purchases }- \text { proceeds from sales of other companies, } \\
& \text { subsidiaries or large assets (i.e. asset transfers between } \\
& \text { companies) }\end{aligned}$ \\
\hline & Other investment & $\begin{aligned}= & \text { Net purchases of other entities debt securities and } \\
& \text { some hedging costs }\end{aligned}$ \\
\hline
\end{tabular}

Source: RBA

17 The starting point for this analysis is based on the source and uses of funds analysis in Black, Kirkwood and Shah Idil (2009). 
A final adjustment is made to account for funding outflows, as this reduces funds available for physical investment. This typically occurs for external equity funding as dividend payments are often larger than equity issuance. In these instances, it is assumed that the funding outflow is financed proportionally by the sources that have positive inflows in a given reporting period.

\section{References}

Black S, J Kirkwood and S Shah Idil (2009), 'Australian Corporates' Sources and Uses of Funds', RBA Bulletin, October, pp 1-12.

Connolly E and D Orsmond (2011), 'The Mining Industry: From Bust to Boom,' RBA Research Discussion Paper No 2011-08.

Debelle G (2010), 'Bank Funding and Capital Flows', Speech to the 23rd Australasian Finance and Banking Conference, Sydney, 15 December.

Debelle G (2011), 'In Defence of Current Account Deficits', Speech to the ADBI/UniSA Workshop on Growth and Integration in Asia, Adelaide, 8 July.

Holloway J, I Roberts and A Rush (2010), 'China's Steel Industry', RBA Bulletin, December, pp 19-25.

Rayner V and J Bishop (2013),'Industry Dimensions of the Resource Boom: An Input-Output Analysis', RBA Research Discussion Paper No 2013-02.

RBA (Reserve Bank of Australia) (2011), 'Box B: The Mining Sector and the External Accounts', Statement on Monetary Policy, November, pp 42-44.

Williams T (2012), 'Exploration and the Listed Resource Sector', RBA Bulletin, September, pp 37-42. 
62 RESERVE BANK OF AUSTRALIA 